\title{
Sub-cloning of the Wild-type proAB Region of the Escherichia coli Genome
}

\author{
By DAVID J. HAYZER \\ Center for Biomedical Research, The Population Council, 1230 York Avenue, New York, \\ New York 10021, U.S.A.
}

(Received 3 February 1983; revised 12 April 1983)

\begin{abstract}
The genes pro $A$ and proB encoding the first two enzymes of the proline biosynthetic sequence in Escherichia coli were subcloned from a ColE1 hybrid plasmid containing 23.3 kilobases of genomic DNA. pro $A$ and $p r o B$ are contiguous and constitute a single operon transcribed in the direction proB-proA. The pro operon is contiguous with the gene phoE. Hybridization experiments showed no homology between pro $A B$ of $E$. coli and the other regions of the $E$. coli genome or with the DNA of several other bacterial species.
\end{abstract}

\section{INTRODUCTION}

Proline biosynthesis in prokaryotes requires the reduction of the $\gamma$-carboxyl group of glutamate to yield glutamic acid 5-semialdehyde which then undergoes a non-enzymic cyclization and internal Schiff's base formation to give $\Delta^{1}$-pyrroline 5 -carboxylate. This is subsequently reduced to proline (Vogel \& Davies, 1952). The reduction of glutamate to the semialdehyde proceeds in two stages, probably by way of the $\gamma$-phosphorylation of glutamate, a sequence mediated by the enzymes $\gamma$-glutamyl kinase (ATP : L-glutamate 5-phosphotransferase; EC 2.7.2.11) (Baich, 1969) and glutamate semialdehyde dehydrogenase [L-glutamate-5semialdehyde: NADP+ oxidoreductase (phosphorylating); EC 1.2.1.41] (Hayzer \& Leisinger, 1982). Both enzymes from Pseudomonas aeruginosa have been partially purified (Krishna \& Leisinger, 1979; Krishna et al., 1979) while the semialdehyde dehydrogenase from Escherichia coli has been purified to homogeneity (Hayzer \& Leisinger, 1982). There is also some evidence that a similar sequence of reactions may be found in certain animal tissues as part of the ornithine biosynthetic pathway (Menslee \& Jones, 1982).

Regulatory control of the flow of carbon through the $E$. coli proline biosynthetic pathway is believed to reside in the feedback inhibition of the kinase by the final product L-proline (Baich \& Pierson, 1965; Baich, 1969). Control at the nucleic acid level by any mechanism, however, has not been demonstrated as it has been with other amino acid biosynthetic pathways (Yanofsky, 1981); the measured levels of the proline enzymes in wild-type cells after growth on minimal medium with or without proline do not appear to differ (Hayzer \& Leisinger, 1980).

Mutations of two genetic loci in E. coli (Bachmann \& Low, 1980), Salmonella typhimurium (Sanderson \& Hartman, 1978) and Pseudomonas aeruginosa (Pemberton \& Holloway, 1972) result in a nutritional requirement satisfied by either proline or its immediate precursor $\Delta^{1}$ pyrroline-5-carboxylate. In $E$. coli the locus designated pro $A$ has been shown to code for the second enzyme in the pathway, glutamate semialdehyde dehydrogenase with proB coding for the $\gamma$-glutamyl kinase (Hayzer \& Leisinger, 1980). Available mapping data are weighted towards the close proximity of proA to proB (Condamine, 1971) although there have also been reports that the two loci may be physically separated by a distance equivalent to $0.6 \mathrm{~min}$ of the genetic map (Broda, 1974) or 23.0 kb (Bachmann \& Low, 1980) and even with an identifiable gene between them (Roberts \& Reeve, 1970).

Genetical studies of the proline pathway would be greatly assisted by the cloning of the pro $A B$ region of the $E$. coli genome and would permit one to establish the physical relationship of the 
Table 1. Bacteria and plasmids used in this study

\begin{tabular}{|c|c|c|}
\hline Strain or plasmid & Genotype or properties & Source or reference \\
\hline Escherichia coli $\mathrm{CSH} 52$ & $F^{-}$thi ara $\Delta($ lac pro $)$ str $A$ rec $A\left(\phi 80\right.$ dlac $\left.^{+}\right)$ & Miller (1972) \\
\hline CSH52/pLC44-11 & as CSH52/pLC44-11 & Hayzer \& Leisinger (1980) \\
\hline RR-1 & 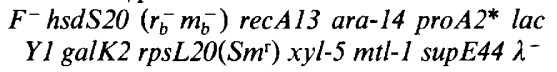 & This laboratory \\
\hline RR-1/pE202 & as $\mathrm{RR}-1 / \mathrm{pE} 202$ & This study \\
\hline RR-1/pEH21 & as $\mathrm{RR}-1 / \mathrm{pEH} 21$ & This study \\
\hline RR-1/pHBE1 & as $\mathrm{RR}-1 / \mathrm{pHBE} 1$ & This study \\
\hline RR-1/pPBB4 & as $\mathrm{RR}-1 / \mathrm{pPBB} 4$ & This study \\
\hline RR-1/pHEP8 & as $\mathrm{RR}-1 / \mathrm{pHEP} 8$ & This study \\
\hline$\chi 680$ & $F^{-} \lambda^{-}$leu thr thi lac tsx strA proA & R. Curtiss III \\
\hline$\chi^{2} 78$ & $F^{-} \lambda$-leu thr thi lac tsx strA proB & R. Curtiss III \\
\hline$\chi^{277}$ & $F^{-} \lambda^{-}$leu thr thi lac tsx strA proC & R. Curtiss III \\
\hline$\chi^{2} 210$ & $F^{-} \lambda$-leu thr thi lac tsx strA & R. Curtiss III \\
\hline$\chi^{4} 662$ & $F^{-}$leu lys met trp ara lac mal xyl strA proA & R. Curtiss III \\
\hline$\chi^{474}$ & $F^{-}$leu lys met trp ara lac mal xyl strA proB & R. Curtiss III \\
\hline$\chi^{478}$ & $F^{-}$leu lys met trp ara lac mal xyl strA proC & R. Curtiss III \\
\hline Pseudomonas aeruginosa $\mathrm{PAO}-1$ & Wild-type & Th. Leisinger \\
\hline Streptococcus faecalis RU-6 & Wild-type & This laboratory \\
\hline Staphylococcus epidermidis RU-4 & Wild-type & This laboratory \\
\hline Staphylococcus epidermidis RU-7 & Wild-type & This laboratory \\
\hline Plasmid pBR322 & $A p^{r} T c^{r}$ & This laboratory \\
\hline pLC $44-11$ & $\mathrm{ColEl}^{\mathrm{Imm}} \mathrm{Pro}^{+}$ & Clarke \& Carbon (1976) \\
\hline pE202 & $\mathrm{Ap}^{r} \mathrm{Tc}^{r} \mathrm{Pro}^{+}$ & This study \\
\hline $\mathrm{pEH} 21$ & $\mathrm{Ap}^{r} \mathrm{Tc}^{\mathrm{s}} \mathrm{Pro}^{+}$ & This study \\
\hline pHBE 1 & $\mathrm{Ap}^{r} \mathrm{Tc}^{s}$ Pro $^{+}$ & This study \\
\hline pPBB4 & $\mathrm{Ap}^{\mathrm{s}} \mathrm{Tc}^{\mathrm{s}}$ Pro $^{+}$ & This study \\
\hline pHEP8 & $\mathrm{Ap}^{\mathrm{s}} \mathrm{Tc}^{\mathrm{r}}$ Pro $^{-}$ & This study \\
\hline
\end{tabular}

genes, how many operons are present and any possible regulatory mechanisms. To this purpose a multi-copy ColE1 hybrid plasmid from the Clarke and Carbon colony bank (Clarke \& Carbon, 1976), known to contain within it the desired genes (Hayzer \& Leisinger, 1980) was used as the starting point for the subcloning and structural analysis described in this paper.

\section{METHODS}

Bacteria and culture conditions. The strains used in this study are listed in Table 1. Non-selective medium was LB-broth and resistance to antibiotics was determined using the same medium but it contained $50 \mu \mathrm{g}$ ampicillin (Ap) or tetracycline $(\mathrm{Tc}) \mathrm{ml}^{-1}$. Selection for the $\mathrm{Pro}^{+}$phenotype was on minimal medium M63 (Pardee \& Prestidge, 1961) containing $0.5 \%(\mathrm{w} / \mathrm{v})$ glucose and an excess $\left(200 \mu \mathrm{g} \mathrm{ml}^{-1}\right)$ of each amino acid, other than proline, required by the strain in question. Media were solidified with $1.5 \%(\mathrm{w} / \mathrm{v})$ agar (Difco). For DNA preparations bacteria were grown to mid-exponential phase $\left(A_{650}=0.5\right)$ on LB-broth unless indicated and where possible including ampicillin or tetracycline $\left(50 \mu \mathrm{g} \mathrm{m}^{-1}\right)$. Staphylococci were grown on Trypticase Soy Broth (BBL). All incubations were at $37^{\circ} \mathrm{C}$.

Plasmid and total DNA preparations. The plasmid DNA of mid-exponential phase cells was amplified by the addition of chloramphenicol $\left(200 \mu \mathrm{g} \mathrm{ml}^{-1}\right)$ and prolonging the incubation for a further $16 \mathrm{~h}$. The cells from 1 litre culture were harvested at $10000 \mathrm{~g}$ for $10 \mathrm{~min}$ and resuspended in $20 \mathrm{ml}$ buffer A (Tris/HCl, $50 \mathrm{~mm}$; EDTA, $20 \mathrm{~mm}$; $\mathrm{pH} 8.0)$ containing $10 \mathrm{mg}$ lysozyme and incubated at $37^{\circ} \mathrm{C}$ for $30 \mathrm{~min}$. Then $0.25 \mathrm{vol}$. SDS-EDTA $(20 \%$, w/v, and $20 \mathrm{mM}$, respectively, pH 8.0) was added to give a clear lysate followed by $0.25 \mathrm{vol} .5 \mathrm{M}-\mathrm{NaCl}$ and centrifugation at $27000 \mathrm{~g}$ for $60 \mathrm{~min}$. Plasmid DNA was concentrated by polyethylene glycol precipitation (Humphreys et al., 1975), collected by centrifugation and redissolved in $20 \mathrm{ml}$ buffer A. Nucleic acid was precipitated overnight at $-20^{\circ} \mathrm{C}$ with 2 vol. ethanol, collected by centrifugation and resuspended in $2 \mathrm{ml}$ buffer A and $6 \mathrm{ml}$ water containing caesium chloride $(8.0 \mathrm{~g})$ and ethidium bromide $(4.0 \mathrm{mg}$ in $0.8 \mathrm{ml}$ water). Centrifugation was in a Beckman Ti50 rotor at $3.8 \times 10^{4}$ r.p.m. for $40 \mathrm{~h}$. The lower, supercoiled DNA band was removed by bottom puncture of the tube, extracted three times with an equal volume of $n$-butanol equilibrated with TE buffer (Tris/ $\mathrm{HCl}, 10 \mathrm{~mm}$; EDTA $1.0 \mathrm{~mm} ; \mathrm{pH} 8.0$ ) and dialysed against the same for $8 \mathrm{~h}$. The DNA was precipitated overnight at $-20^{\circ} \mathrm{C}$ by 0.2 vol. 3 M-sodium acetate and 2 vol. ethanol, centrifuged, dried in vacuo and redissolved in TE buffer for storage at $4^{\circ} \mathrm{C}$. Total DNA, chromosomal and plasmid combined, was prepared by the procedure 
of Marmur (Johnson, 1981). For screening transformants for plasmid content, the mini lysate method of Birnboim \& Doly (1979) was used.

Restriction endonuclease digestions and ligation procedure. Endonuclease reactions were carried out in a buffer containing Tris/ $\mathrm{HCl}, 50 \mathrm{~mm} ; \mathrm{MgCl}_{2}, 5 \mathrm{~mm}$; DTT, $1 \mathrm{mM}$ and $\mathrm{NaCl}, 50 \mathrm{mM}, \mathrm{pH} 7 \cdot 4$. With SalI, AvaII and Hinf I the DTT was omitted and with $P$ stI (including double digests with $S a l \mathrm{I}$ ) the buffer included Tris/ $\mathrm{HCl}, 50 \mathrm{mM}$; $\mathrm{MgCl}_{2}, 10 \mathrm{mM}$ and $\left(\mathrm{NH}_{4}\right)_{2} \mathrm{SO}_{4}, 50 \mathrm{mM}$ at $\mathrm{pH} \mathrm{7.5}$. All digestions were overnight at $37^{\circ} \mathrm{C}$ except with $\mathrm{Hpal}$ which was for only $2 \mathrm{~h}$. Before ligations the enzymes were inactivated at $80^{\circ} \mathrm{C}$ for $10 \mathrm{~min}$. A total of $4 \mu \mathrm{g}$ DNA fragments were ligated overnight at $4{ }^{\circ} \mathrm{C}$ by $1.0 \mathrm{U}$ of $\mathrm{T}_{4}$ DNA ligase using the manufacturers protocol.

Electrophoresis. Intact plasmid DNA and fragments of $8 \cdot 0-0.5 \mathrm{~kb}$ were analysed in $0.7 \%$ agarose gels with Tris/borate buffer (Tris base, $45 \mathrm{~mm}$; boric acid, $45 \mathrm{mM}$ and EDTA, $1.5 \mathrm{~mm}$ at $\mathrm{pH} \mathrm{7.85}$ ) at $4-10 \mathrm{~V} \mathrm{~cm}^{-1}$. Phage- $\lambda$ DNA digested with EcoRI and EcoRI-HindIII were used as standards. Fragments of 1.5-0.05 kb were analysed in $5 \%$ acrylamide gels with the same buffer at $6 \mathrm{~V} \mathrm{~cm}^{-1}$ with HinfI and HaeIII digested plasmid pBR322 as the standards.

Transformation. Mid-exponential phase cultures of $50 \mathrm{ml}\left(A_{650}=0.5\right)$ were centrifuged and the cells resuspended in $20 \mathrm{ml}$ cold $100 \mathrm{mM}-\mathrm{CaCl}_{2}$ for $20 \mathrm{~min}$. After centrifugation at $5000 \mathrm{~g}$ for $10 \mathrm{~min}$, they were resuspended in $0.5 \mathrm{ml}$ of the $\mathrm{CaCl}_{2}$ and $0.1 \mathrm{ml}$ samples were mixed with $1.0-4.0 \mu \mathrm{g} \mathrm{DNA}$, cooled on ice for $30 \mathrm{~min}$ and heat-shocked at $37^{\circ} \mathrm{C}$ for $6 \mathrm{~min}$. After $45 \mathrm{~min}$ on ice the cell suspensions were diluted into $1.0 \mathrm{ml} \mathrm{LB}$-broth and incubated at $37^{\circ} \mathrm{C}$ with gentle shaking for $1 \mathrm{~h}$ prior to spreading $0.05-0.2 \mathrm{ml}$ samples on to selective media. Plates were incubated for $24-48 \mathrm{~h}$.

Nick-translation labelling of plasmid DNA. Plasmid pPBB4 $(0 \cdot 5 \mu \mathrm{g})$ cut with SalI was incubated with dATP, dGTP and dTTP, $20 \mu \mathrm{M}$ of each, ${ }^{32} \mathrm{P}$-dCTP, $50 \mu \mathrm{Ci}(1.85 \mathrm{MBq})$ and $2 \mathrm{U}$ DNA polymerase I in Tris/ $\mathrm{HCl}, 50 \mathrm{mM}$, pH 7.5 containing $\mathrm{MgSO}_{4}, 10 \mathrm{mM}$ and DTT, $1 \mathrm{mM}$. After $1 \mathrm{~h}$ at $15^{\circ} \mathrm{C}$ the unincorporated nucleotides were removed by a Sephadex G-50 column $(0.5 \times 7.0 \mathrm{~cm})$ and the DNA precipitated at $-20^{\circ} \mathrm{C}$ overnight with yeast tRNA $\left(60 \mu \mathrm{g} \mathrm{ml}^{-1}\right), 0.5 \mathrm{M}$-potassium acetate and $2 \mathrm{vol}$. ethanol.

Filter hybridization. Samples of total DNA cut with restriction endonucleases were electrophoresed in $1.0 \%$ agarose gels and denatured and transferred to nitrocellulose filters as described by Southern (1975). Hybridizations were by the method of Thomas (1980) except that filters were washed at room temperature twice with $6 \times$ standard saline citrate (SSC) buffer and four times with SSC $2 \times$ (each wash containing $0 \cdot 1 \%$ SDS). SSC buffer contained $0 \cdot 15 \mathrm{M}-\mathrm{NaCl}$ and $0 \cdot 015 \mathrm{M}$-sodium citrate at $\mathrm{pH} 7 \cdot 0$. Autoradiography used Kodak X-omat film with an enhancing screen at $-70^{\circ} \mathrm{C}$ for $3-48 \mathrm{~h}$.

\section{RESULTS}

\section{Restriction endonuclease cleavage mapping of plasmid pLC44-11}

The first step in the subcloning of the pro $A B$ gene region was the determination of a restriction cleavage map of the source DNA, plasmid pLC44-11 (Fig. 1). The fragment sizes within the $5.0 \mathrm{~kb}$ Sal I region and the estimated size of pLC44-11 of $29.7 \mathrm{~kb}$, the means of two independent experimental values, were in agreement with those reported by Tommassen et al. (1982). One gene, phoE, encoding the outer membrane porin PhoE was reported to lie within the $2.0 \mathrm{~kb}$ SalI$E c o$ RI fragment and to contain the single Pst I site of this region. The exact locations of the two extremes of phoE were not established (Tommassen et al., 1982). Earlier transductional analysis of the phoE-arg $F$ region of the chromosome gave the gene order of $p h o E$-proAB-argF and showed that phoE and proAB are very closely linked at the $6 \mathrm{~min}$ position on the $E$. coli gene map (Tommassen \& Lugtenberg, 1981). These published data, however, was not sufficient to locate pro $A B$ relative to $p h o E$ and the ColE1 vector DNA of $\mathrm{pLC} 44-11$ nor, indeed, to estimate how far apart the various regions are, in terms of kb pairs.

Only the largest of the EcoRI fragments could contain the ColE1 DNA $(6.4 \mathrm{~kb})$. HindIII and BamHI sites within the other two EcoRI fragments are not present in ColE1. In addition, since approximately $5.3 \mathrm{~kb}$ of ColE1 is uncut by Pst I (Edlund et al., 1979) if the vector was in the reverse orientation to that shown in Fig. 1 there would be a 6.7 SalI-Pst I fragment, not the $1.45 \mathrm{~kb}$ fragment found.

\section{Subcloning of the proAB gene region}

Plasmid pLC44-11 was cleaved with the restriction endonucleases EcoRI, HindIII, BamHI or SalI and the resulting fragments were ligated into the vector $\mathrm{pBR} 322$ cut with the corresponding enzymes. Transformations were made into $E$. coli RR-1 carrying a deletion of the pro loci (Tommassen et al., 1981) with the primary selection for the $\mathrm{Pro}^{+}$phenotype. An incubation 


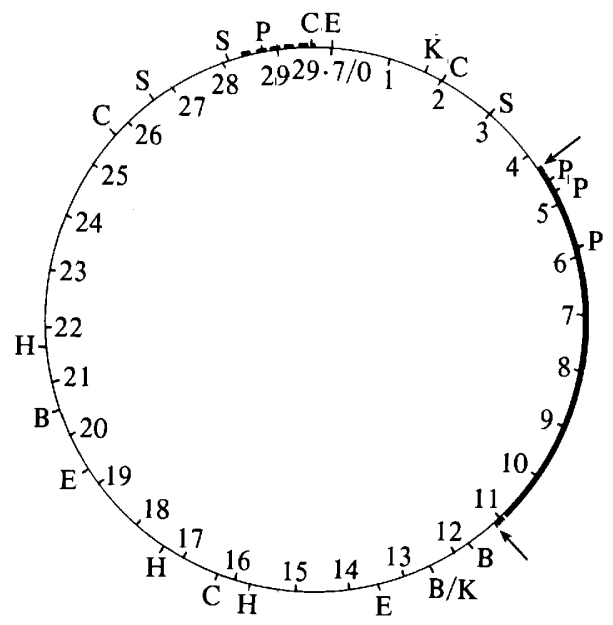

Fig. 1. Circular restriction map of the ColE1 hybrid plasmid pLC44-11. Cleavage sites are given for restriction endonucleases EcoRI, E; HindIII, H; BamHI, B; SalI, S; PstI, P; KpnI, K; and BglII, C. The available data did not allow all of the Pst I sites to be located. Pst I fragments of $0 \cdot 37,0 \cdot 58,1 \cdot 11$, $1 \cdot 46,1 \cdot 6,1 \cdot 6,3 \cdot 0,5 \cdot 95$, and $7 \cdot 25 \mathrm{~kb}$ pairs were found. ColEl vector DNA is indicated by the heavy line and the approximate position of the phoE gene by _._. (Tommassen et al., 1982). The positions of the poly(dA.dT) connectors (Clarke \& Carbon, 1976) are arrowed. The scale given by the figures inside the circle is in $\mathrm{kb}$ pairs.

period of $48 \mathrm{~h}$ was usually required to obtain such colonies which were replica-plated on to ampicillin or tetracycline-containing medium to show the presence of pBR322 DNA although they were routinely maintained on minimal medium lacking proline. Only EcoRI-cut pLC44-11 and pBR322 yielded any antibiotic-resistant (in this case $\mathrm{Ap}^{\mathrm{r}} \mathrm{Tc}^{\mathrm{r}}$ ) proline-independent isolates with mini lysate analysis showing the presence of plasmids greater than $4.3 \mathrm{~kb}$ in size. One isolate, carrying the smallest plasmid, was selected for further examination. The plasmid, designated $\mathrm{pE2} 202$, was subjected to restriction endonuclease cleavage which showed that the $11.0 \mathrm{~kb} E c o \mathrm{RI}$ fragment of pLC44-11 had been subcloned (Fig. 2) and therefore proA and proB were shown to be anticlockwise to $p h o E$ in the pLC44-11 cleavage map given in Fig. 1.

A further reduction in the size of the insert carrying $\operatorname{pro} A$ and $\operatorname{pro} B$ was achieved by a double digestion of pE202 with EcoRI and HindIII followed by ligation into EcoRI-HindIII-cut pBR322, thereby inactivating the tetracycline resistance gene of the vector. Again, the smallest plasmid found in a proline-independent transformant of $E$. coli RR-1 was selected, designated $\mathrm{pEH} 21$ and mapped by endonuclease cleavage (Fig. 2). An even greater reduction in the size of the insert was obtained by cutting pE202 with both HindIII and $B g I I I$ with ligation into pBR322 cleaved with $H$ indIII and BamHI ( $B g l \mathrm{II}$ and BamHI generate different 4-base 5'-extensions, the terminal two bases of each being complementary thus generating a sequence, upon the subsequent in vivo addition of the missing bases, which cannot be cut by either of the original enzymes but instead forms a novel Sau3a or MboI recognition site).

The resulting minimum sized plasmid selected, pHBE1, carried an insert of $4.44 \mathrm{~kb}$ and included most of the phoE gene (approximately $1.2 \mathrm{~kb}$ ) in addition to pro $A$ and proB (Fig. 2). Restriction analysis also showed that while pHBEl included the single HindIII end and the HpaI site (marked with an asterisk in Fig. 2) of pE202 and pEH21 much of the region between including four Pst I sites (the precise positions of which could not be determined and therefore are not indicated in Fig. 2) and single PvuII and BglII sites, had been deleted. One end of the deletion lay between $H p a I^{*}$ and the $P v u I I-B g l I I$ sites, separated by about $0.4 \mathrm{~kb}$ while the other end was approximately $0.6 \mathrm{~kb}$ from the HindIII site.

The final stage in the reduction of the insert length was accomplished by the removal of most of the remaining phoE DNA. pEH21 was cut by PstI and BglII, ligated into PstI-BamHI-cut pBR322 and transformed into strain RR-1. Selection was for the Pro ${ }^{+}$phenotype. Plasmid 


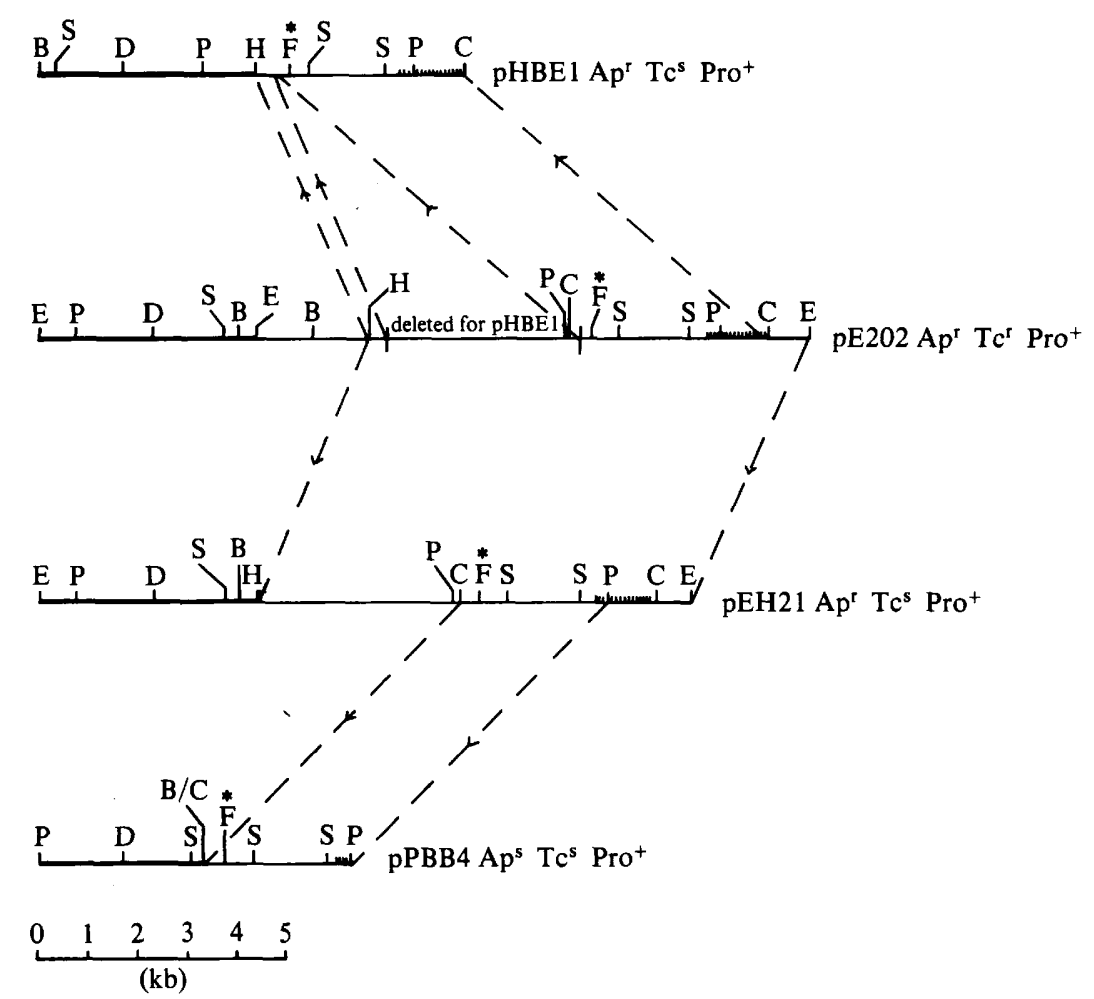

Fig. 2. Subcloning of the pro $A B$ region of the $E$. coli genome from the $E c o$ RI insert of plasmid pE202. Vector DNAs are given by the heavy lines and the approximate position of the phoE gene by m.m. The double vertical line between the HindIII and $H p a I^{*}$ sites of pHBEl indicate where a region of pE202 was deleted. Restriction sites are designated as in Fig. 1 with the additions of PvuII, D and HpaI, F.

pPBB4 thus obtained contained a $2.92 \mathrm{~kb}$ insert and a $3.23 \mathrm{~kb}$ vector DNA region. One end of the remaining phoE DNA lay between the PstI junction and the PvuII/HincII-SalI site. These latter three could not be distinguished. The extent of the residual phoE DNA could be estimated from the coding capacity required for $\gamma$-glutamyl kinase with a subunit approximately $4.3 \times 10^{4} \mathrm{Dal}$ in size (unpublished data) and glutamate semialdehyde dehydrogenase with a subunit of $4.7 \times 10^{4}$ Dal (Hayzer \& Leisinger, 1982) each equivalent to $1.2-1 \cdot 3 \mathrm{~kb}$ of DNA; i.e. about $2.5 \mathrm{~kb}$ in total. The remaining $400-500$ bases of the pPBB4 insert represents the maximum phoE region carried by pPBB4. A detailed restriction cleavage map of pPBB4 is shown in Fig. 3 with individual fragment sizes given in Table 2.

\section{Localization of the deletion which occurred during the formation of plasmid pHBE1}

Endonuclease $H p a I$ was used to confirm the positioning of certain fragments within the map shown in Fig. 3 and to localize one of the ends of the deletion that occurred during the formation of pHBE1. Thus, the 500 base $A l u$ fragment was cleaved by $H p a I$ to 280 and 200 base lengths, the 288 base $\operatorname{Sau} 96$ fragment was cleaved to 170 and 88 base lengths, the 600 base $D d e$ fragment to 320 and 280 bases, the 205 base Hinf I fragment to 190 and 15 bases and the HaeIII 235 base fragment to 175 and 60 bases. Furthermore, these same fragments were present and similarly cleaved when either pHBE1 or pPBB4 was the source DNA, demonstrating that the deletion from $\mathrm{pE} 202$ which occurred during the construction of pHBE1 was limited at one end to a point between the DdeI site (marked with + ) and the BglII/BamHI insert-vector junction of pPPB4 (Fig. 3).

The approximate position of the opposite end of the deletion from pE202 was determined from the Pst I-HpaI distance of pHBEl of $1.52 \mathrm{~kb}$ of which $0.78 \mathrm{~kb}$ was contained within the 


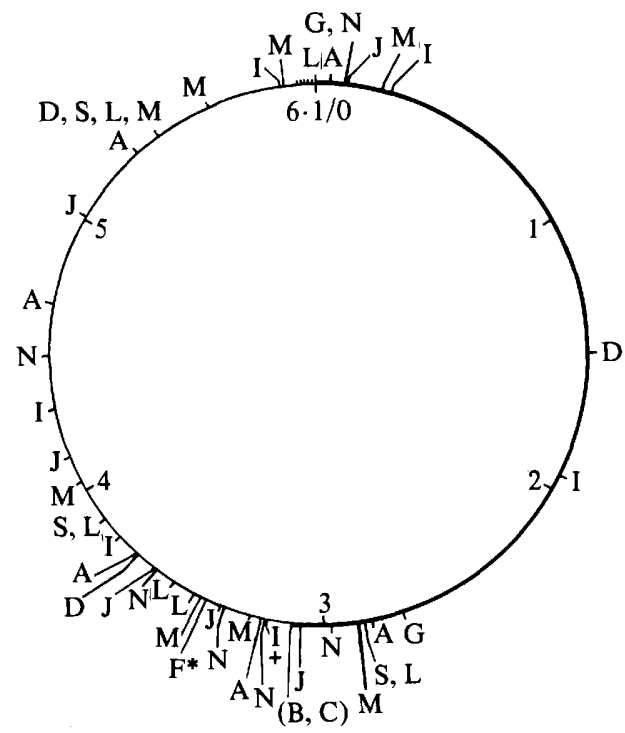

Fig. 3. Detailed restriction cleavage map of plasmid pPBB4. pBR322 vector DNA is given by the heavy line. Only those cuts within the pBR322 region which result in a fragment containing part of the insert are shown. Those Hinf I and HaeIII fragments which could not be positioned are marked with an asterisk in Table 2. Restriction sites are designated as in Figs 1 and 2 with the additions of AluI, A; AvaII, G; DdeI, I; HaeIII, J;HincII, L;Hinf I, M; and Sau 96, N.

\section{Table 2. Restriction endonuclease cleavage products of plasmid pPBB4}

All values are the means of two determinations.

\begin{tabular}{|c|c|}
\hline Enzyme/s & Fragment sizes (kb pairs) \\
\hline Pst $\mathrm{I}$ & $6 \cdot 15$ \\
\hline SalI & $3 \cdot 57,1 \cdot 45,1 \cdot 02$ \\
\hline PvulI & $2 \cdot 27,2 \cdot 13,1 \cdot 64$ \\
\hline AvalI $\dagger$ & 3.45 \\
\hline HincII & $3 \cdot 45,1 \cdot 45,0 \cdot 645,0 \cdot 34,0 \cdot 096$ \\
\hline PstI-SalI & $3 \cdot 02,1 \cdot 49,1 \cdot 06,0 \cdot 59$ \\
\hline Pst I-PvuII & $2 \cdot 31,1 \cdot 75,1 \cdot 54,0 \cdot 62$ \\
\hline Sall-PvuII & $2 \cdot 14,1 \cdot 47,1 \cdot 36,0 \cdot 84,0 \cdot 32$ \\
\hline Alu $†$ & $1 \cdot 0,0 \cdot 77,0 \cdot 63,0 \cdot 505,0 \cdot 403$ \\
\hline AluI-PstI & $1 \cdot 075,0 \cdot 715,0 \cdot 65,0 \cdot 515,0 \cdot 403$ \\
\hline AluI-SalI & $0 \cdot 82,0 \cdot 735,0 \cdot 63,0 \cdot 505,0 \cdot 335,0 \cdot 151$ \\
\hline AluI-PvuII & $1 \cdot 025,0 \cdot 80,0 \cdot 645,0 \cdot 505,0 \cdot 403$ \\
\hline AluI-HincII & $0 \cdot 85,0 \cdot 75,0 \cdot 665,0 \cdot 6,0 \cdot 365,0 \cdot 290,0 \cdot 200,0 \cdot 092,0 \cdot 074$ \\
\hline Sau96† & $1 \cdot 6,0 \cdot 905,0 \cdot 285,0 \cdot 249,0 \cdot 249$ \\
\hline Sau96-PstI & $1 \cdot 587,0 \cdot 915,0 \cdot 287,0 \cdot 237,0 \cdot 237,0 \cdot 105$ \\
\hline Sau96-SalI & $0 \cdot 865,0 \cdot 815,0 \cdot 660,0 \cdot 285,0 \cdot 255,0 \cdot 249$ \\
\hline Sau96-Pvull & $0 \cdot 865,0 \cdot 815,0 \cdot 287,0 \cdot 245,0 \cdot 245$ \\
\hline Sau96-HincII & $0 \cdot 79,0 \cdot 710,0 \cdot 610,0 \cdot 249,0 \cdot 185,0 \cdot 170,0 \cdot 153,0 \cdot 142,0 \cdot 126,0 \cdot 092,0 \cdot 087,0 \cdot 079$ \\
\hline DdeI & $1 \cdot 675,1 \cdot 200,0 \cdot 620,0 \cdot 546,0 \cdot 409$ \\
\hline DdeI-PstI & $1 \cdot 675,1 \cdot 200,0 \cdot 620,0 \cdot 546,0 \cdot 284,0 \cdot 182$ \\
\hline DdeI-SalI & $1 \cdot 100,0 \cdot 885,0 \cdot 620,0 \cdot 490,0 \cdot 43,0 \cdot 300,0 \cdot 116,0 \cdot 409$ \\
\hline DdeI-PvuII & $1 \cdot 250,1 \cdot 050,0 \cdot 520,0 \cdot 49,0 \cdot 409,0 \cdot 126$ \\
\hline DdeI-HincII & $1 \cdot 100,0 \cdot 850,0 \cdot 500,0 \cdot 445,0 \cdot 409,0 \cdot 360,0 \cdot 325,0 \cdot 280,0 \cdot 094$ \\
\hline Hinfl $\dagger$ & $0 \cdot 754^{*}, 0 \cdot 593,0 \cdot 344,0 \cdot 310^{*}, 0 \cdot 298^{*}, 0 \cdot 253^{*}, 0 \cdot 243^{*}, 0 \cdot 220^{*}, 0 \cdot 220,0 \cdot 089^{*}, 0 \cdot 054^{*}$ \\
\hline HinfI-PstI & $0 \cdot 754,0 \cdot 596,0 \cdot 310,0 \cdot 298,0 \cdot 255,0 \cdot 243,0 \cdot 243,0 \cdot 220,0 \cdot 220,0 \cdot 112,0 \cdot 089,0 \cdot 054$ \\
\hline HinfI-SalI & $0 \cdot 743,0 \cdot 436,0 \cdot 344,0 \cdot 307,0 \cdot 298,0 \cdot 248,0 \cdot 240,0 \cdot 220,0 \cdot 201,0 \cdot 160,0 \cdot 090,0 \cdot 053$ \\
\hline HinfI-HincII & $0 \cdot 730,0 \cdot 344,0 \cdot 335,0 \cdot 310,0 \cdot 298,0 \cdot 245,0 \cdot 238,0 \cdot 198,0 \cdot 193,0 \cdot 165,0 \cdot 092,0 \cdot 055$ \\
\hline HaeIII & $1 \cdot 120,0 \cdot 565,0 \cdot 300^{*}, 0 \cdot 234^{*}, 0 \cdot 215^{*}, 0 \cdot 145^{*}, 0 \cdot 114^{*}, 0 \cdot 104^{*}, 0 \cdot 073^{*}, 0 \cdot 057^{*}$ \\
\hline Pst $\mathrm{I}$ & $1 \cdot 000,0 \cdot 57,0 \cdot 302,0 \cdot 234,0 \cdot 215,0 \cdot 135,0 \cdot 118,0 \cdot 118,0 \cdot 104,0 \cdot 072,0 \cdot 057$ \\
\hline HaeIII-SalI & $0 \cdot 740,0 \cdot 365,0 \cdot 320,0 \cdot 300,0 \cdot 251,0 \cdot 234,0 \cdot 213,0 \cdot 125,0 \cdot 114,0 \cdot 104,0 \cdot 072,0.057$ \\
\hline HaeIII-PvuII & $0 \cdot 770,0 \cdot 557,0 \cdot 434,0 \cdot 345,0 \cdot 295,0 \cdot 231,0 \cdot 213,0 \cdot 132,0 \cdot 115,0 \cdot 104,0 \cdot 072,0 \cdot 057$ \\
\hline
\end{tabular}

* HinfI and HaeIII fragments marked thus could not be positioned on the cleavage map shown in Fig. 3.

† Only those fragments specific to the insert of pPBB4 are given. 

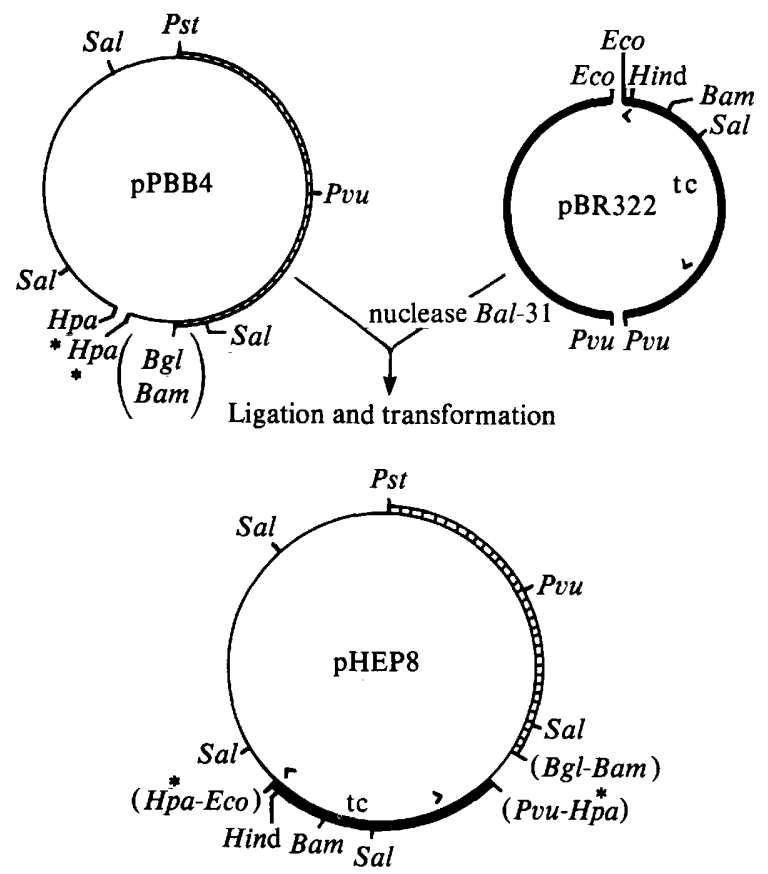

Fig. 4. Formation and endonuclease cleavage map of plasmid pHEP8. Plasmid pPBB4 was cut with HpaI. pBR322 was cut with EcoRI and PvuII. The DNA $(50 \mu \mathrm{g})$ was precipitated with ethanol, resuspended in water $(10 \mu \mathrm{l})$ and incubated with nuclease $B a l-31(2 \mathrm{U})$ and reaction buffer according to manufacturers instructions for $30 \mathrm{~min}$ at $37^{\circ} \mathrm{C}$. The DNA was phenol extracted and ethanol precipitated, dissolved in $10 \mu \mathrm{l}$ water and ligated with the cleaved pPBB4 and transformed as described in Methods. 2 pBR322 DNA.

pBR322 vector (Fig. 2). Since one end of the deletion was $0 \cdot 3-0 \cdot 4 \mathrm{~kb}$ from the $\mathrm{HpaI}$ site, within the DdeI-BglII section the other must be about $0.5 \mathrm{~kb}$ from the HindIII site of pHBE1. Thus the region lost from pE202 was approximately $3.8 \mathrm{~kb}$ in length.

\section{Insertional inactivation of the proline biosynthetic gene system}

Inactivation of either proA or proB in pPBB4 would also be expected to eliminate the only selective markers present on the plasmid since both the ampicillin and tetracycline resistant determinants of pBR322 were no longer intact. To allow one of the pro genes to be inactivated and at the same time provide a means of selecting such a mutant the EcoRI-PvuII $2.07 \mathrm{~kb}$ fragment of pBR322, carrying the entire region coding for tetracycline resistance (Sutcliffe, 1978) was inserted into the single $H p a I$ site of pPBB4. The EcoRI-PvuII fragment was pretreated with nuclease $B a l-31$ to remove the cohesive EcoRI $5^{\prime}$ strand prior to the blunt-end ligation into the recipient and transformation into $E$. coli RR-1. Those transformants with the $\mathrm{Tc}^{\mathrm{r}} \mathrm{Ap}^{s} \mathrm{Pro}^{-}$phenotype were examined for their plasmid content, in particular for a plasmid approximating $8.0 \mathrm{~kb}(6.1 \mathrm{~kb}$ from $\mathrm{pPBB} 4$ plus $2.07 \mathrm{~kb}$ from $\mathrm{pBR} 322)$. The cleavage map of the plasmid from one such isolate, pHEP8, is given in Fig. 4 and shows the orientation of the $2.07 \mathrm{~kb}$ insert which resulted in Sall fragments of 2.08 and $1.1 \mathrm{~kb}$; the alternative orientation would have given fragments of 1.86 and $1.31 \mathrm{~kb}$. No EcoRI site was found but the HindIII site was present indicating the limit of $\mathrm{Bal}-31$ digestion.

Insertion of the foreign DNA into the single $\mathrm{HpaI}$ site of pPBB4 resulted in the loss of proline independence for the $E$. coli RR-1 transformant. This endonuclease site must therefore lie within either proA or proB. To establish which gene was affected, pHEP8 and the parental pPBB4 were each transformed into a series of different proline requiring mutants. Selection, in the case of pPBB4 was for proline independence and with pHEP8, initially for tetracycline resistance and subsequently for proline independence. Both plasmids failed to complement proC mutants. 
Table 3. Transformations of proline-auxotrophic strains of Escherichia coli by plasmids pPBB4 and $\mathrm{pHEP} 8$

\begin{tabular}{|c|c|c|c|c|c|c|c|c|c|}
\hline \multirow[b]{2}{*}{$\begin{array}{l}\text { Transforming } \\
\text { plasmid }\end{array}$} & \multirow[b]{2}{*}{$\begin{array}{l}\text { Phenotype } \\
\text { selected }\end{array}$} & \multicolumn{8}{|c|}{ Recipient strain and relevant genotype } \\
\hline & & $\begin{array}{l}\mathrm{RR}-1 \\
\Delta \text { proA }\end{array}$ & $\begin{array}{l}\text { CSH52 } \\
\triangle \text { proAB }\end{array}$ & $\begin{array}{l}\chi 277 \\
\text { proC }\end{array}$ & $\begin{array}{l}\chi 278 \\
\text { proB }\end{array}$ & $\begin{array}{l}\chi 680 \\
\text { proA }\end{array}$ & $\begin{array}{l}\chi 462 \\
\text { proA }\end{array}$ & $\begin{array}{l}\chi 474 \\
\text { proB }\end{array}$ & $\begin{array}{l}\chi 478 \\
\text { proC }\end{array}$ \\
\hline $\begin{array}{l}\text { pPBB4 } \\
\text { pHEP8 }\end{array}$ & $\begin{array}{c}\mathrm{Pro}^{+} \\
\mathrm{Tc}^{+} \\
\text {Pro }^{+}\end{array}$ & $\begin{array}{l}+ \\
+ \\
-\end{array}$ & $\begin{array}{l}+ \\
+ \\
-\end{array}$ & $\begin{array}{l}- \\
+ \\
-\end{array}$ & $\begin{array}{l}+ \\
+ \\
-\end{array}$ & $\begin{array}{l}+ \\
+ \\
-\end{array}$ & $\begin{array}{l}+ \\
+ \\
-\end{array}$ & $\begin{array}{l}+ \\
+ \\
-\end{array}$ & $\begin{array}{l}- \\
+ \\
-\end{array}$ \\
\hline
\end{tabular}

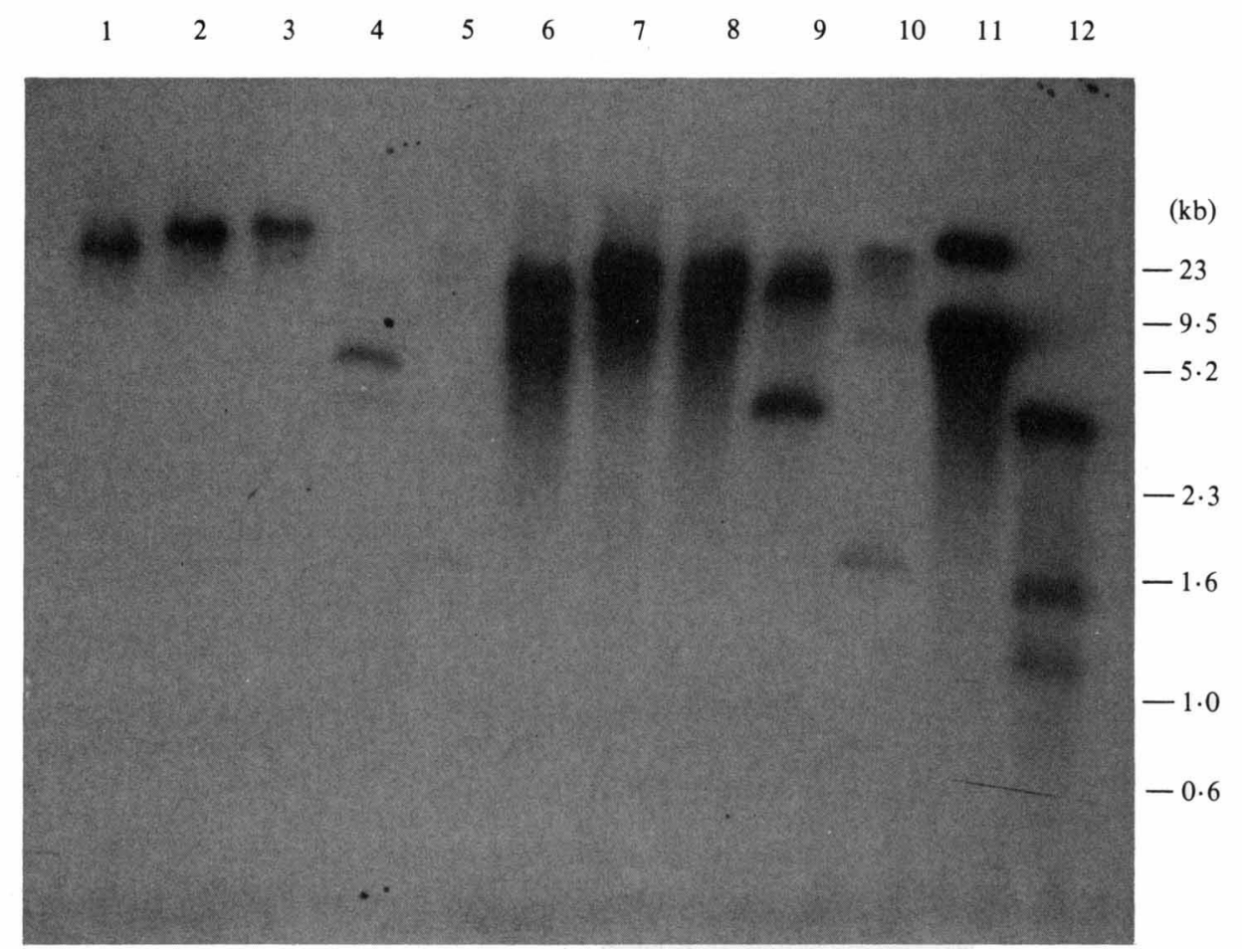

Fig. 5. Gel electrophoretic and hybridization analysis of total bacterial DNA preparations cleaved with restriction endonucleases. Tracks $1-5, E$. coli $\chi 210$ cleaved with EcoRI, HindIII, BamHI, Pst I or SalI, respectively; Tracks 6-10, E. coli CSH52/pLC44-11 cleaved with EcoRI, HindIII, BamHI, Pst I or SalI, respectively; tracks 11 and $12, E$. coli RR-1/pPBB4 cleaved with $P s t$ I or SalI, respectively. Tracks 1-5 contained $3 \cdot 3 \mu \mathrm{g}$ DNA, tracks 6-10 $2 \cdot 1 \mu \mathrm{g}$, and 11-12 0.8 $\mu \mathrm{g}$. All digestions were overnight at $37^{\circ} \mathrm{C}$ with approximately $5 \mathrm{U}$ of an enzyme used. The $\mathrm{kb}$ values shown were determined from $\lambda \mathrm{DNA}$ digested with EcoRI and EcoRI plus HindIII.

pPBB4 conferred proline independence upon all the other strains as expected. pHEP8, however, failed to give any $\mathrm{Pro}^{+}$transformants even though the $\mathrm{Tc}^{\mathrm{r}}$ phenotype showed that the plasmid had entered the cells (Table 3). Mini lysate analysis of randomly selected transformants confirmed the plasmids used were indeed present

\section{Hybridization of plasmid pPBB4 with total bacterial DNAs}

${ }^{32} \mathrm{P}$-labelled pPBB4 was used as a probe to detect homologous regions in bacterial total DNA preparations following digestion with restriction endonucleases and the separation of the fragments by agarose electrophoresis. 
Single bands of homologous DNA with sizes greater than $19.0 \mathrm{~kb}$ were found when the DNA from E. coli $\chi 210$, a proline prototroph, was digested with EcoRI, HindIII or BamHI. PstI gave a strong band of $6.0 \mathrm{~kb}$ and two weaker bands at 3.4 and $11.0 \mathrm{~kb}$. SalI gave three bands, two faint at about 20 and $14 \mathrm{~kb}$ and a stronger one at $1.45 \mathrm{~kb}$ (Fig. 5). This latter was also present, as expected, in DNA from strain CSH52 carrying the plasmid pLC44-11 since this fragment overlapped pro $A$ and proB and was present in all the subclones.

The DNA from strain CSH52/pLC44-11 when cut with EcoRI, HindIII or BamHI gave single hybridizable fragments, all greater than $15 \mathrm{~kb}$ each (other experiments, not shown, give an $E c o$ RI band at about $10 \mathrm{~kb}$ ). Inspection of the restriction cleavage map for pLC44-11 (Fig. 1) shows similar fragments carrying the entire Pst I-BglII region subsequently subcloned into pPBB4. There was a prominent $3.4 \mathrm{~kb}$ Pst I band, as expected and one or two larger pieces, presumably due to homology between the ColE1 region of pLC44-11 and the pBR322 vector DNA of pPBB4. All three SalI fragments of pLC44-11 had regions homologous with pPBB4.

DNA from strain RR-1/pPBB4 cleaved with SalI gave the three bands expected from the cleavage map of $\mathrm{pPBB} 4$. No others were seen. Pst $\mathrm{I}$ unexpectedly gave a band, in addition to that at $6.0 \mathrm{~kb}$ due to the uniquely cleaved plasmid, in a position corresponding to a size greater than $23 \mathrm{~kb}$, possibly as a result of concatameric plasmid forms which prevent $P$ st I digestion. This is supported by finding no such anomaly with SalI digestions.

No homologous bands were found with DNA from E. coli strains CSH52 and RR-1, which carry deletions of proA and proB, when pLC44-11 or pPBB4 were absent or with Pseudomonas aeruginosa, Streptococcus faecalis or Staphylococcus epidermidis DNA, even with the low stringency washing of the filters, high loadings of the agarose gels with digested DNA (up to $50 \mu \mathrm{g}$ DNA per track) and with exposures of the hybridized filters to the autoradiographic films for periods five to ten times as long as the sample shown in Fig. 5.

\section{DISCUSSION}

Escherichia coli genomic DNA contained within the hybrid plasmid pLC44-11 includes both the pro $A$ and $p r o B$ genes (Hayzer \& Leisinger, 1980). The phoE gene is also present and all three loci are closely linked at the 6 min genomic position (Tommassen et al., 1981). Subcloning of the genes conferring proline independence into an $E$. coli strain with a deletion of pro $A B$, as described in this paper, has allowed the isolation of a $2.9 \mathrm{~kb}$ fragment of DNA at least $85 \%$ of which consists of the two genes. Thus there is little possibility of intermediate genes; pro $A$ and proB are contiguous with one another and with phoE, at least in the strain of $E$. coli, CS520 (Clarke \& Carbon, 1976), used as the source of DNA in constructing the original ColE1 hybrid plasmid.

The insertion of foreign DNA, in this case a $2.07 \mathrm{~kb}$ fragment of pBR322 carrying the intact gene for tetracycline resistance, into pPBB4 inactivated both pro genes. The novel plasmid failed to complement the mutations carried by pro $A$ or pro $B$ strains and strongly supported the existence of a single pro operon with polarity of transcription in the direction of proB-proA. Such a possibility has previously been proposed as the basis of certain pro $B$ mutants which lack both enzyme activities. The likelihood of double mutations was not supported by the observed rate of spontaneous reversion of proline auxotrophy (Hayzer \& Leisinger, 1980). The results described in this paper clearly show that a mutation at a single defined site produced a similar ProA- $\mathrm{B}^{-}$ phenotype although the actual enzyme levels were not investigated. The insertional inactivation does fail, however, to distinguish between the location of the $H p a I$ site within the proB structural gene or a preceding regulatory region.

It would be interesting to examine in greater detail those $E$. coli strains reported to have a gene between pro $A$ and proB (Roberts \& Reeve, 1970). If such a situation does exist, it would imply either the addition of a new promotion site before pro $A$ or the loss of such in the creation of the strain, or its ancestor, from which the proBA operon cloned in this present series of experiments originated. The existence of the $1.45 \mathrm{~kb}$ SalI fragment could be used as an indicator of contiguous pro $A$ and $p r o B$ genes.

The construction of plasmid pHBE1 was possible because of an apparently spontaneous 
deletion of approximately $3.8 \mathrm{~kb}$ between the HindIII and HpaI sites of pE202. No obvious mechanism for this occurrence is evident, such as the existence of insertion elements in the regions at the termini of the deleted segment and a suitable explanation, if possible, might have to await a much more detailed analysis of this region of the $E$. coli genome.

The isolation of the entire proBA operon should now facilitate studies into the question of whether there is coregulation of the synthesis of the two enzymes encoded, perhaps from the determination of the nucleotide sequence of the region preceding the structural genes and thus to detect an attenuator region similar to that associated with other amino acid biosynthetic pathways (Yanofsky, 1981).

Sequencing of the subcloned proAB region will also permit a comparison with the pro genes from other sources and even with genes encoding enzymes of related functions found in other metabolic pathways, e.g. the aspartokinases of threonine-methionine-lysine synthesis, glutamine synthetase, and $N$-acetylglutamyl kinase and $N$-acetylglutamic acid semialdehyde dehydrogenase of arginine biosynthesis. In P. aeruginosa the pro genes are not closely linked on the genome (Royle et al., 1981) and have no apparent homology with the corresponding E. coli genes reflecting their evolutionary divergence.

Recently the proBA region of the S. typhimurum genome has been isolated (LeRudulier \& Valentine, 1982). The restriction map of a $10 \cdot 3 \mathrm{~kb} E c o$ RI fragment carrying the two genes appear to be very similar to that found for the corresponding E. coli region (Fig. 1) indicative of the very close sequence homology between the two species in this part of their respective genomes.

I thank Dr Samuel S. Koide in whose laboratory this work was carried out and Dr T. Taketo for help with illustrations. My thanks also to Jean Schweis and Richard Hale for their assistance in the preparation of the manuscript.

\section{REFERENCES}

BaChMANN, B. J. \& Low, K. B. (1980). Linkage map of Escherichia coli K-12, edition 6. Microbiological Reviews 44, 1-56.

BaICH, A. (1969). Proline synthesis in Escherichia coli. A proline-inhibitible glutamic acid kinase. Biochimica et biophysica acta 192, 462-467.

Baich, A. \& Pierson, D. J. (1965). Control of proline biosynthesis in Escherichia coli. Biochimica et biophysica acta 104, 397-404.

Birnboim, M. C. \& Doly, J. (1979). A rapid alkaline extraction procedure for screening recombinant plasmid DNA. Nucleic Acids Research 7, 1513-1524.

BRODA, P. (1974). Modified map positions for lac and pro markers in Escherichia coli K12. Journal of Bacteriology 117, 741-746.

Clarke, L. \& Carbon, J. A. (1976). Colony bank containing synthetic ColE1 hybrid plasmids representative of the entire $E$. coli genome. Cell 9, 91-99.

Condamine, H. (1971). Mutants des voies de biosynthese et de dégradation de la proline chez Escherichia coli (K12). Annales de l'Institut Pasteur 120, 9-22.

EdLUND, T., GrundSTrom, T. \& Normark, S. (1979). Isolation and characterization of DNA repetitions carrying the chromosomal $\beta$-lactamase gene of Escherichia coli K-12. Molecular and General Genetics 173, 115-125.

HAYZer, D. J. \& Leisinger, Th. (1980). The geneenzyme relationships of proline biosynthesis in Escherichia coli. Journal of General Microbiology 118 , 287-293.

Hayzer, D. J. \& Leisinger, Th. (1982). Proline biosynthesis in Escherichia coli: purification and characterisation of glutamate semialdehyde dehy- drogenase. European Journal of Biochemistry 121, 561-565.

Humphreys, G. O., Willshaw, G. A. \& Anderson, E. S. (1975). A simple method for the preparation of large quantities of pure plasmid DNA. Biochimica et biophysica acta 383, 457-463.

JoHnson, J. L. (1981). Genetic characterisation. In Manual of Methods of General Bacteriology, p. 452. Washington, D.C.: American Society of Microbiology.

Krishna, R. V. \& LeIsINGER, TH. (1979). Biosynthesis of proline in Pseudomonas aeruginosa. Partial purification and characterisation of $\gamma$-glutamyl kinase. Biochemical Journal 181, 215-222.

Krishna, R. V., Beilstein, P. \& Leisinger, TH. (1979). Biosynthesis of proline in Pseudomonas aeruginosa. Properties of $\gamma$-glutamyl phosphate reductase and 1-pyrroline-5-carboxylate reductase. Biochemical Journal 181, 223-230.

LeRudulier, D. \& Valentine, R. C. (1982). Genetic engineering in agriculture: osmoregulation. Trends in Biochemical Sciences 7, 431-433.

Menslee, J. C. \& Jones, M. E. (1982). Ornithine synthesis from glutamate in rat small intestinal mucosa. Archives of Biochemistry and Biophysics 219 , 186-197.

Miller, J. H. (1972). Experiments in Molecular Genetics. Cold Spring Harbor, New York: Cold Spring Harbor Laboratory.

PARdee, A. B. \& Prestidge, L. S. (1961). The initial kinetics of enzyme induction. Biochimica et biophysica acta 49, 77-88.

Pemberton, J. \& Holloway, B. W. (1972). Chromo- 
some mapping in Pseudomonas aeruginosa. Genetical Research 19, 251-260.

Roberts, L. M. \& ReEve, E. C. R. (1970). Two mutations giving low level streptomycin resistance in Escherichia coli K-12. Genetical Research 16, 359365.

Royle, P. L., Matsumoto, H. \& Holloway, B. W. (1981). Genetic circularity of the Psuedomonas aeruginosa PAO chromosome. Journal of Bacteriology 145, 145-155.

Sanderson, K. E. \& Hartman, P. E. (1978). Linkage map of Salmonella typhimurium. Microbiological Reviews 43, 471.

SOUTHERN, E. M. (1975). Detection of specific sequences among DNA fragments separated by gel electrophoresis. Journal of Molecular Biology 98, 503-517.

SuTCLIFFE, J. G. (1978). Complete nucleotide sequence of the Escherichia coli plasmid pBR322. Cold Spring Harbor Symposium on Quantitative Biology 43, 77-90.

THOMAS, P.S. (1980). Hybridisation of denatured RNA and small DNA fragments transferred to nitrocellulose. Proceedings of the National Academy of Sciences of the United States of America 77, 5201-5205.
Tommassen, J. \& Lugtenberg, B. (1981). Localisation of $p h o E$, the structural gene for outer membrane protein e in Escherichia coli K12. Journal of Bacteriology 147, 118-123.

Tommassen, J., VAN Der Ley, P. \& LugTenberg, B. (1981). Genetic and biochemical characterisation of an Escherichia coli K-12 mutant with an altered outer membrane protein. Antonie van Leeuwenhoek 47, 325-337.

Tommassen, J., Overduir, P., Lugtenberg, B. \& Bergmans, H. (1982). Cloning of phoE, the structural gene for the Escherichia coli phosphate limitationinducible outer membrane pore protein. Journal of Bacteriology 149, 668-672.

Vogel, H. J. \& Davies, B. D. (1952). Glutamic $\gamma$ semialdehyde and $\Delta^{1}$-pyrroline-5-carboxylic acid, intermediates in the biosynthesis of proline. Journal of the American Chemical Society 74, 109-112.

YANOFSKY, C. (1981). Attenuation in the control of expression of bacterial operons. Nature, London 289 , $751-758$. 